\title{
O PAPEL DO ENFERMEIRO NA COMISSÃO DE CONTROLE DE INFECÇÃO HOSPITALAR E A ADEQUAÇÃO DAS ATIVIDADES QUE VEM EXECUTANDO
}

\author{
Rúbia Aparecida Lacerda*
}

\section{NOTA PRÉVIA}

LACERDA, R.A. O papel do enfermeiro na Comissão de Controle de Infecção Hospitalar e a adequação das atividades que vem executando. Nota prévia. Rev. Esc. Enf. USP, São Paulo, 19(2):189-190, 1985.

A problemática da infecção adquirida no hospital é um dos assuntos mais relevantes da prática hospitalar atual. No Brasil ocorre, atualmente, uma conscientização pelos profissionais de saúde, das causas e conseqüências da infecção hospitalar.

A Portaria n 196 de 24/06/83 do Ministério da Saúde, estabeleceu a obrigatoriedade da existência, em todos os hospitais, de Comissão de Controle de Infecção Hospitalar (CCIH). As infecções hospitalares constituem, hoje, a quarta causa de morte no País, perdendo apenas para as cardiopatias, gastroenterites e neoplasias em geral.

O estudo a ser desenvolvido, pretende verificar a existência das $\mathrm{CCIH}$ e seus membros nos hospitais do Município de São Paulo. É objetivo deste estudo, analisar o papel da enfermeira nessas comissões e comparar as atividades que vem executando com as referidas na bibliografia.

LACERDA, R.A. The role of the nurse in the "Central of the Hospital Infections Committee". Preliminary note. Rev. Esc. Enf. USP, São Paulo, 19(2): - , 1985.

The problem of infections acquired in hospitals is one of the most relevant subjects in current hospital practice. In Brasil, there is nowadays, a definite awarences of the its possible sources and consequences, among the professional health personnel.

A 1983 ordinance of the Ministry of Health makes compulsory the existance of a "Control of Hospital Infections Committee" in each hospital. This is due to the fact that hospital infections are the fourty

- Enfermeira. Aluna do Curso de Pós-graduação, nivel Mestrado, da Escola de Enfermagem da USP. 
cause of death in this country, coming right after cardiac diseases, gastrointestinal diseases and neoplasms.

The objectives of this study are:

1 - to verify the existance of such committees in the city of São Paulo hospitals, and who are their members;

2 - to analyse the role of the nurses in these committees and to comparelier activities with the ones refered in the specific bibliography. 